\title{
KEWENANGAN PERAWAT MELAKSANAKAN PELAYANAN FARMASI KLINIK DISPENSING SEDIAAN STERIL DI RUMAH SAKIT MENURUT UNDANG-UNDANG NOMOR 38 TAHUN 2014 TENTANG KEPERAWATAN DIHUBUNGKAN DENGAN ASAS PELINDUNGAN DAN KESELAMATAN PASIEN STUDI KASUS DI RSUD SEKARWANGI KABUPATEN SUKABUMI
}

\author{
Doni Irawan \\ Magister Ilmu Hukum Pascasarjana Universitas Islam Bandung \\ E-mail : doni.irawan80@gmail.com
}

\begin{abstract}
Abstrak: Dispensing sediaan steril seharusnya dilakukan secara aseptis oleh tenaga kefarmasian di Instalasi Farmasi Rumah Sakit, tetapi kenyataannya masih dilakukan oleh perawat dengan sarana dan pengetahuan yang sangat terbatas. Tujuan dari penelitian ini untuk mengetahui dan memahami kewenangan perawat melaksanakan pelayanan farmasi klinik dispensing sediaan steril di RSUD Sekarwangi Kabupaten Sukabumi, implementasi kewenangan perawat melaksanakan pelayanan farmasi klinik dispensing sediaan steril di RSUD Sekarwangi Kabupaten Sukabumi, dan mekanisme pemberian kewenangan perawat melaksanakan pelayanan farmasi klinik dispensing sediaan steril di RSUD Sekarwangi Kabupaten Sukabumi menurut Undang-Undang Nomor 38 Tahun 2014 tentang Keperawatan dihubungkan dengan asas pelindungan dan keselamatan pasien. Metode pendekatan yang digunakan dalam penelitian ini adalah yuridis normatif dengan meneliti bahan-bahan hukum primer, sekunder dan tersier yang diperoleh dari studi kepustakaan yang terkait dengan topik yang diteliti, dan kemudian dianalisis menggunakan metode deskriptif kualitatif. Hasil penelitian ini menunjukkan bahwa kewenangan perawat melaksanakan pelayanan farmasi klinik dispensing sediaan steril di RSUD Sekarwangi Kabupaten Sukabumi tidak dinyatakan dan dijelaskan dalam Undang-Undang Nomor 38 Tahun 2014 tentang Keperawatan. Pelaksanaan pelayanan farmasi klinik dispensing sediaan steril di RSUD Sekarwangi Kabupaten Sukabumi belum dilakukan oleh apoteker dan tenaga teknis kefarmasian tapi dilaksanakan oleh perawat dengan dasar pelimpahan wewenang secara delegatif dari tenaga kefarmasian kepada perawat. Belum ada pasal yang menyatakan dan menjelaskan mengenai mekanisme pemberian kewenangan perawat melaksanakan pelayanan farmasi klinik dispensing sediaan steril di dalam Undang-Undang Nomor 38 Tahun 2014 tentang Keperawatan.
\end{abstract}

\section{Kata kunci: Kewenangan, Perawat, Dispensing Sediaan Steril}

Abstract: Dispensing sterile preparations should be aseptically conducted by pharmacists at the Hospital Pharmacy Installation, but in reality, they are still conducted by nurses with very limited facilities and knowledge. This study aimed at describing and understanding the authority of nurses to conduct clinical pharmacy services in dispensing sterile preparations at Regional Public Hospital 
(RSUD/Rumah Sakit Umum Daerah) Sekarwangi, Sukabumi District, the implementation of the authority of nurses to conduct clinical pharmacy services of dispensing sterile preparations at RSUD Sekarwangi, Sukabumi District, and the mechanism of granting authority of nurses conducting clinical services of dispensing clinical preparations sterile in RSUD Sekarwangi, Sukabumi Regency according to Law Number 38 Year 2014 concerning Nursing related to the principles of patient protection and safety. The approach used normative juridical by examining primary, secondary, and tertiary legal materials obtained from literature study related to the topic under study, and then analyzed using qualitative descriptive method. The result indicates that the authority of nurses to conduct clinical pharmacy services of dispensing sterile preparations at RSUD Sekarwangi, Sukabumi District was not stated and explained in Law Number 38 Year 2014 concerning Nursing. The implementation of clinical pharmacy services of dispensing sterile preparations in RSUD Sekarwangi, Sukabumi District had not been conducted out by pharmacists and pharmaceutical technical staff, but was conducted by nurses based on delegation of authority from pharmaceutical personnel to nurses. There is no article that states and explains the mechanism for granting authority for nurses to conduct clinical pharmacy services of dispensing sterile preparations in Law Number 38 Year 2014 concerning Nursing.

Keywords: Authority, Nurses, Dispensing Sterile Preparations

\section{A. PENDAHULUAN}

Kesehatan sebagai salah satu unsur kesejahteraan umum harus diwujudkan sesuai cita-cita bangsa Indonesia sebagaimana dimaksud dalam pembukaan Undang-Undang Dasar 1945 melalui pembangunan yang berkesinambungan berdasarkan Pancasila dan Undang-Undang Dasar 1945. ${ }^{1}$ Setiap orang berhak hidup sejahtera lahir dan batin, bertempat tinggal dan mendapatkan lingkungan

1 Endang Kusuma Astuti, Transaksi Terapeutik Dalam Upaya Pelayanan Medis di Rumah Sakit, PT. Citra Aditya Bakti, Semarang, 2006, Hlm. 2. hidup yang baik dan sehat serta berhak memperoleh pelayanan kesehatan. ${ }^{2}$ Terminologi kesehatan bukan sekedar permasalahan fisik, sebagaimana menurut World Health Organization (WHO); "Health is a state of complete physical, mental and social well-being and not merely the absence of disease of infirmity". Artinya: "Sehat adalah keadaan yang sempurna, baik fisik maupun sosial,

\footnotetext{
2 Undang-Undang Dasar 1945, Pasal 28H ayat (1).

${ }^{3}$ Ta'adi, Hukum Kesehatan Berbasis Pada Keadilan, Genta Publishing, Yogyakarta, 2017, Hlm. 1.
} 
tidak hanya terbebas dari penyakit atau kelemahan/cacat”.

Kewenangan atau authority pada dasarnya merupakan bentuk lain dari kekuasaan yang sering kali dipergunakan dalam sebuah organisasi. Kewenangan merupakan kekuasaan formal atau terlegitimasi. Dalam sebuah organisasi, seseorang yang ditunjuk atau dipilih untuk memimpin suatu organisasi, bagian, atau departemen memiliki kewenangan atau kekuasaan yang terlegitimasi. ${ }^{4}$ Kewenangan untuk melaksanakan upaya kesehatan itulah yang memerlukan peraturan hukum sebagai dasar pembenaran hukum wewenang kesehatan tersebut. Peraturan hukum tentang upaya kesehatan saja belum cukup karena upaya kesehatan penyelenggaraannya disertai pendukung berupa sumber daya kesehatan baik yang berupa perangkat keras maupun perangkat lunak. Bidang sumber daya kesehatan inilah yang yang dapat memasuki kegiatan pelayanan kesehatan. Untuk mencapai

4 Ernie Tisnawati Sule dan Kurniawan Saefullah, Pengantar Manajemen, Kencana, Jakarta,2017, Hlm. 175. peningkatan pelayanan kesehatan bagi seluruh lapisan masyarakat Indonesia yang jumlah penduduknya amat besar bukan pekerjaan mudah, oleh sebab itu diperlukan juga peraturan perlindungan hukum untuk melindungi pemberi dan penerima jasa pelayanan kesehatan. ${ }^{5}$ Hukum tidak terlepas dari kehidupan manusia yang dalam kehidupannya memiliki berbagai kepentingan. ${ }^{6}$

Pelayanan kesehatan sebagai kegiatan utama rumah sakit menempatkan perawat sebagai salah satu tenaga kesehatan yang paling dekat hubungannya dengan pasien dalam penanganan penyakitnya. $^{7}$ Perawat adalah seseorang yang telah lulus pendidikan tinggi keperawatan, baik di dalam maupun di luar negeri yang diakui oleh pemerintah sesuai dengan ketentuan peraturan Perundang-undangan. Asuhan keperawatan adalah rangkaian interaksi perawat dengan klien dan

\footnotetext{
5 Hendrik, Etika dan Hukum Kesehatan, EGC, Jakarta, 2013, Hlm. 26.

${ }^{6}$ Jurnal. Eksistensi Hukum Perawat Sebagai Tenaga Kesehatan Selain Tenaga Kefarmasian Terhadap Hak Atas Pelayanan Kesehatan.

7 Sri Praptianingsih, Kedudukan Hukum Perawat Dalam Upaya Pelayanan Kesehatan di Rumah Sakit, PT. Raja Grafindo Persada, Jakarta, 2006, Hlm. 3.
} 
lingkungannya untuk mencapai tujuan pemenuhan kebutuhan dan kemandirian klien dalam merawat dirinya. ${ }^{8}$

\section{Menurut Peraturan Menteri}

Kesehatan Republik Indonesia

Nomor 72 Tahun 2016 tentang Standar Pelayanan Kefarmasian di Rumah Sakit, dispensing sediaan steril harus dilakukan di Instalasi Farmasi dengan teknik aseptik untuk menjamin sterilitas dan stabilitas produk dan melindungi petugas dari paparan zat berbahaya serta menghindari terjadinya kesalahan pemberian Obat. Pencampuran obat suntik seharusnya dilakukan oleh apoteker di Instalasi Farmasi Rumah Sakit, tetapi kenyataannya semua masih dilaksanakan oleh tenaga kesehatan lain dengan sarana dan pengetahuan yang sangat terbatas, sedangkan pekerjaan kefarmasian tersebut memerlukan teknik khusus dengan latar belakang pengetahuan antara lain sterilitas, sifat fisikokimia dan stabilitas obat, ketidakcampuran

8 Undang-Undang Republik Indonesia Nomor 38 Tahun 2014 tentang Keperawatan, Pasal 1 ayat (2), ayat (3), ayat (5). obat serta risiko bahaya pemaparan obat. $^{9}$

Dispensing sediaan steril merupakan rangkaian perubahan bentuk obat dari kondisi semula menjadi produk baru dengan proses pelarutan atau penambahan bahan lain yang dilakukan secara aseptis oleh apoteker di sarana pelayanan kesehatan. ${ }^{10}$ Kegiatan dispensing sediaan steril meliputi pencampuan obat suntik, penyiapan nutrisi parenteral dan penanganan sediaan sitostatik. $^{11}$ Metode ini meliputi tahap penyiapan, pencampuran, penyimpanan, dan pembuangan. Setiap tahap erat kaitannya dengan ketersediaan sumber daya manusia, peralatan, dan ruang. ${ }^{12}$

\footnotetext{
9 Departemen Kesehatan Republik Indonesia, Pedoman Pencampuran Obat Suntik dan Penanganan Sediaan Sitostatika, Direktorat Bina Farmasi Komunitas dan Klinik, Ditjen Bina Kefarmasiaan dan Alat Kesehatan, 2009, Hlm. 3.

10 Departemen Kesehatan Republik Indonesia. Pedoman Dasar Dispensing Sediaan Steril. Direktorat Bina Farmasi Komunitas dan Klinik, Ditjen Bina Kefarmasiaan dan Alat Kesehatan, 2009.

11 Lihat Lampiran Peraturan Menteri Kesehatan Republik Indonesia Nomor 72 Tahun 2016 tentang Standar Pelayanan Kefarmasian di Rumah Sakit.

${ }^{12}$ Pharmaceutical Journal of Indonesia. Uji Kesesuaian Aseptic Dispensing Berdasarkan Pedoman Dasar Dispensing Sediaan Steril Departemen Kesehatan RI di NICU dan ICU
} 
Di RSUD Sekarwangi

Kabupaten Sukabumi, pelayanan farmasi klinik dispensing sediaan steril belum dilakukan oleh tenaga kefarmasian, tapi dilakukan oleh perawat karena belum tersedianya sarana dan prasarana di instalasi farmasi rumah sakit serta belum cukup dan terampilnya sumber daya manusia kefarmasian. Pelayanan farmasi klinik dispensing sediaan steril yang dilakukan oleh perawat meliputi pencampuan obat suntik dan penyiapan nutrisi parenteral.

Dari paparan latar belakang diatas, ada beberapa hal yang dapat diidentifikasikan dan menarik untuk dibahas dalam penelitian ini, yakni bagaimana kewenangan perawat melaksanakan pelayanan farmasi klinik dispensing sediaan steril, bagaimana implementasi kewenangan perawat melaksanakan pelayanan farmasi klinik dispensing sediaan steril, dan bagaimana mekanisme pemberian kewenangan perawat melaksanakan pelayanan farmasi klinik dispensing sediaan steril di RSUD Sekarwangi

RSUD. Dr. Saiful Anwar Malang, 2017, Hlm. 33.
Kabupaten Sukabumi menurut Undang-Undang Nomor 38 Tahun 2014 tentang Keperawatan dihubungkan dengan Asas Pelindungan dan Keselamatan Pasien.

\section{B. PEMBAHASAN}

\section{Kewenangan}

Perawat

Melaksanakan

Pelayanan

Farmasi Klinik Dispensing

Sediaan Steril di RSUD

Sekarwangi

Kabupaten

\section{Sukabumi}

Kewenangan atau authority pada dasarnya merupakan bentuk lain dari kekuasaan yang sering kali dipergunakan dalam sebuah organisasi. Kekuasaan merupakan kekuasaan formal atau terlegitimasi. Dalam sebuah organisasi, seseorang yang ditunjuk atau dipilih untuk memimpin suatu organisasi, bagian, atau departemen memiliki kewenangan atau kekuasaan yang terlegitimasi. Seseorang yang ditunjuk untuk memiliki kewenangan dalam mengatur berbagai hal yang terkait dengan sumber daya manusia 
atau orang-orang yang terdapat di dalam organisasi. ${ }^{13}$

Secara yuridis, pengertian wewenang adalah kemampuan yang diberikan oleh peraturan perundangundangan yang menimbulkan akibatakibat hukum. ${ }^{14}$

Ketentuan kewenangan perawat dalam melaksanakan tugas pelayanan farmasi klinik dispensing sediaan steril di rumah sakit belum diatur secara jelas dalam Undang-Undang Nomor 38 Tahun 2014 tentang Keperawatan. Pada Pasal 33 ayat (4) huruf c, dijelaskan bahwa "Dalam melaksanakan tugas pada keadaan keterbatasan tertentu, perawat berwenang melakukan pelayanan kefarmasian secara terbatas dalam hal tidak terdapat tenaga kefarmasian". Yang dimaksud dengan "pelayanan kefarmasian secara terbatas" adalah kegiatan menyimpan dan menyerahkan obat kepada Klien. Penulis tidak menemukan ayat dan penjelasan

13 Ernie Tisnawati Sule dan Kurniawan Saefullah, Pengantar Manajemen, Kencana, Jakarta, 2017. Hlm. 175.

14 Indroharto, Asas-Asas Umum Pemerintahan yang Baik, dalam Paulus Efendie Lotulung, Himpunan Makalah AsasAsas Umum Pemerintahan yang Baik, Citra Aditya Bakti, Bandung, 1994, Hlm. 65. yang menyatakan bahwa pelayanan farmasi klinik dispensing sediaan steril di rumah sakit merupakan wewenang perawat atau dapat dilimpahkan kepada perawat selama menyelenggarakan praktik keperawatan di rumah sakit.

RSUD Sekarwangi Kabupaten Sukabumi merupakan unsur pendukung tugas Bupati, dipimpin oleh Direktur yang berkedudukan di bawah dan bertangungjawab kepada Bupati melalui Sekretariat Daerah mempunyai beberapa peraturan yang menjadi landasan dalam penyelenggaraan urusan pemerintahan. Dalam UndangUndang Republik Indonesia Nomor 32 Tahun 2004 tentang Pemerintah Daerah, khususnya dalam pasal 14 ayat (1) huruf e, telah diatur bahwa salah satu urusan wajib yang menjadi kewenangan pemerintah daerah untuk kabupaten/kota merupakan urusan yang berskala kabupaten/kota adalah penanganan bidang kesehatan. Dengan dasar ini, maka Pemerintah Kabupaten Sukabumi mempunyai wewenang untuk mengatur penanganan terkait dengan 
pemberdayaan tenaga kesehatan sesuai dengan kebutuhan daerahnya.

Peraturan Daerah Kabupaten Sukabumi Nomor 25 Tahun 2012 tentang Organisasi Perangkat Daerah Pemerintah Kabupaten Sukabumi pada Bagian Kedelapan Paragraf 1 Pasal 39 ayat (2) menjelaskan "RSUD Sekarwangi mempunyai tugas melaksanakan penyusanan dan pelaksanaan kebijakan pemerintah daerah di bidang pelayanan kesehatan".

Untuk melaksanakan ketentuan Pasal 39 Peraturan Daerah Kabupaten Sukabumi Nomor 25 Tahun 2012 tentang Organisasi Perangkat Daerah Pemerintah Kabupaten Sukabumi, maka ditetapkan Peraturan Bupati Sukabumi Nomor 81 Tahun 2012 tentang Struktur Organisasi dan Tata Kerja Rumah Sakit Umum Daerah Sekarwangi Kabupaten Sukabumi. Dalam Pasal 2 ayat (2) dijelaskan "RSUD mempunyai tugas pokok melaksanakan penyusunan dan pelaksanaan kebijakan dibidang pelayanan kesehatan". Kemudian dalam Pasal 3 huruf b, dijelaskan “ Untuk melaksanakan tugas pokok sebagaimana dimaksud dalam Pasal 2 ayat (2) RSUD mempunyai fungsi perumusan dan penyusunan kebijakan teknis dibidang pelayanan kesehatan.

Terminologi "kebijakan" sendiri dalam Kamus Besar Bahasa Indonesia berarti "rangkaian konsep dan asas yang menjadi garis besar dan dasar rencana dalam pelaksanaan suatu pekerjaan, kepemimpinan, dan cara bertindak (tentang pemerintahan, organisasi, dan sebagainya), pernyataan cita-cita, tujuan, prinsip, atau maksud sebagai garis pedoman untuk memanajemen dalam usaha mencapai sasaran." Terkait dengan hal ini, kiranya perlu diperhatikan bahwa dalam bahasa Indonesia, istilah "kebijakan" berasal dari kata "bijak" yang artinya pandai, mahir, selalu menggunakan akal budinya. Kata bijak tersebut menjadi kebijakan, yaitu kepandaian; kemahiran; rangkaian konsep dan asas yang menjadi garis besar dan dasar rencana dalam melaksanakan

\footnotetext{
15 Tim Penyusun, Kamus Besar Bahasa Indonesia, Edisi Ketiga, Jakarta, 2002, Hlm. 780.
} 
suatu pekerjaan, kepemimpinan, dan cara untuk bertindak. ${ }^{16}$

Kewenangan

perawat

melaksanakan pelayanan farmasi klinik dispensing sediaan steril di Rumah Sakit Umum Daerah Sekarwangi Kabupaten Sukabumi, yang disadari oleh direktur rumah sakit, komite keperawatan dan apoteker serta tenaga kefarmasian belum diatur secara jelas dalam undang-undang keperawatan, maka apoteker melimpahkan wewenang pelayanan farmasi klinik dispensing sediaan steril dalam bentuk kebijakan direktur berupa Surat Keputusan Direktur Rumah Sakit Umum Daerah Sekarwangi Nomor 445/Kep.267-FARMASI/I/2016

tentang Pencampuran Obat Steril di Rumah Sakit Umum Daerah Sekarwangi Kabupaten Sukabumi. Dasar dikeluarkannya surat keputusan tersebut adalah terbatasnya sumber daya manusia apoteker dan tenaga teknis kefarmasian dan sarana farmasi agar tercapai keselamatan pasien dan tidak tertundanya pengobatan pasien.

\footnotetext{
${ }^{16}$ Anton M. Moeliono, Kamus Besar Bahasa Indonesia, Jakarta, Balai Pustaka, 1990, Hlm. 115.
}

Belum ada standar prosedur operasional mengenai pelimpahan wewenang dari apoteker kepada perawat. Pelaksanaan pelayanan farmasi klinik dispensing sediaan steril dilimpahkan kepada perawat dalam bentuk delegasi juga disertai dengan pelimpahan tanggung jawab.

Menurut penulis, terbitnya Surat Keputusan Direktur Rumah Sakit Umum Daerah Sekarwangi Nomor 445/Kep.267-FARMASI/I/2016 tentang Pencampuran Obat Steril di Rumah Sakit Umum Daerah Sekarwangi Kabupaten Sukabumi sesuai dengan asas-asas yang ada dalam Undang-Undang Nomor 38 Tahun 2014 tentang Keperawatan diantaranya yaitu asas pelindungan dan asas keselamatan pasien, karena rumah sakit berupaya untuk memberikan pelayanan pasien yang lebih aman dengan menerapkan solusi untuk mengurangi serta meminimalkan timbulnya risiko. Yang dimaksud dengan asas pelindungan adalah bahwa pengaturan Praktik Keperawatan harus memberikan pelindungan yang sebesar-besarnya bagi Perawat dan masyarakat. Yang maksud dengan 
asas kesehatan dan keselamatan klien adalah Perawat dalam melakukan Asuhan Keperawatan harus mengutamakan kesehatan dan keselamatan Klien.

Menurut Philipus M. Hadjon, dalam hal pelimpahan wewenang pemerintahan melalui delegasi tersebut terdapat syarat-syarat sebagai berikut, diantaranya delegasi harus definitif dan pemberi delegasi tidak dapat lagi menggunakan sendiri wewenang yang telah dilimpahkan itu. $^{17}$ Berdasarkan uraian tersebut, apoteker selaku pemberi delegasi tidak bisa lagi menggunakan wewenangnya melakukan pelayanan farmasi klinik dispensing sediaan steril karena sudah beralih kepada perawat. Jika merujuk pada Peraturan Menteri Kesehatan Republik Indonesia Nomor 72 tahun 2016 tentang Standar Pelayanan Kefarmasian di Rumah Sakit, pelayanan farmasi klinik dispensing sediaan steril harus dilakukan di Instalasi Farmasi dengan teknik aseptik untuk menjamin sterilitas dan stabilitas produk dan melindungi petugas dari paparan zat berbahaya

${ }^{17}$ Philipus M. Hadjon, op.cit, Hlm. 9-10. serta menghindari terjadinya kesalahan pemberian obat. Penggunakaan kata harus dalam peraturan menteri tersebut penulis artikan sebagai wajib, artinya pelaksanaan pelayanan farmasi klinik dispensing sediaan steril di rumah sakit merupakan kewajiban dari apoteker dan tenaga teknis kefarmasian. Terminologi "harus" sendiri dalam Kamus Besar Bahasa Indonesia berarti patut; wajib; mesti (tidak boleh tidak). ${ }^{18}$

Merujuk pada Undang-Undang Nomor 38 Tahun 2014 tentang Keperawatan, Undang-undang ini merupakan lex specialis bagi profesi keperawatan di Indonesia pada saat ini. Sebagai lex specialis, UndangUndang Nomor 38 Tahun 2014 tentang Keperawatan ini juga membawa asas lex specialis derogat legi generali dan lex superior derogat legi inferior.

Mencermati pasal 29 ayat (1) huruf e dan huruf f, menyatakan:

"Dalam menyelenggarakan Praktik Keperawatan, Perawat bertugas sebagai pelaksana tugas

\footnotetext{
18 https://kbbi.web.id. Diunduh tanggal 3 Juni 2018, jam 10.14 WIB.
} 


berdasarkan pelimpahan
wewenang; dan atau pelaksana
tugas dalam keadaan
keterbatasan tertentu."
Pasal 32 Ayat (1), menyatakan:
"Pelaksanaan tugas berdasarkan
pelimpahan wewenang
sebagaimana dimaksud dalam
Pasal 29 ayat (1) huruf e hanya
dapat diberikan secara tertulis
oleh tenaga medis kepada
Perawat untuk melakukan
sesuatu tindakan medis dan
melakukan
pelaksanaannya."

Pasal 32 Ayat (2), menyatakan:

"Pelimpahan wewenang sebagaimana dimaksud pada ayat (1) dapat dilakukan secara delegatif atau mandat."

Pasal 32 Ayat (3), menyatakan:

"Pelimpahan wewenang secara delegatif untuk melakukan sesuatu tindakan medis diberikan oleh tenaga medis kepada Perawat dengan disertai pelimpahan tanggung jawab.”

Pasal 32 Ayat (5), menyatakan:
"Pelimpahan wewenang secara mandat diberikan oleh tenaga medis kepada Perawat untuk melakukan sesuatu tindakan medis di bawah pengawasan."

Pasal 32 Ayat (6), menyatakan: “Tanggung jawab atas tindakan medis pada pelimpahan wewenang mandat sebagaimana dimaksud pada ayat (5) berada pada pemberi pelimpahan wewenang."

Pasal 33 ayat (1), menyatakan: "Pelaksanaan tugas dalam keadaan keterbatasan tertentu sebagaimana dimaksud dalam Pasal 29 ayat (1) huruf $\mathrm{f}$ merupakan penugasan Pemerintah yang dilaksanakan pada keadaan tidak adanya tenaga medis dan/atau tenaga kefarmasian di suatu wilayah tempat Perawat bertugas."

Pasal 33 ayat (2), menyatakan:

"Keadaan tidak adanya tenaga medis dan/atau tenaga kefarmasian di suatu wilayah tempat Perawat bertugas 
sebagaimana dimaksud pada ayat (1) ditetapkan oleh kepala Satuan Kerja Perangkat Daerah yang menyelenggarakan urusan pemerintahan di bidang kesehatan setempat.”

Pasal 33 ayat (3), menyatakan:

"Pelaksanaan tugas pada keadaan keterbatasan tertentu sebagaimana dimaksud pada ayat (1) dilaksanakan dengan memperhatikan kompetensi Perawat."

Pasal 33 ayat (4), meyatakan:

"Dalam melaksanakan tugas pada keadaan keterbatasan tertentu sebagaimana dimaksud pada ayat (1), Perawat berwenang:

a. melakukan pengobatan untuk penyakit umum dalam hal tidak terdapat tenaga medis;

b. merujuk pasien sesuai dengan ketentuan pada sistem rujukan; dan

c. melakukan pelayanan kefarmasian secara terbatas dalam hal tidak terdapat tenaga kefarmasian.
Berdasarkan Undang-Undang Nomor 38 Tahun 2014 tentang Keperawatan seperti yang penulis uraikan diatas, dapat diketahui bahwa Perawat dalam melaksanakan tugas bisa berdasarkan pelimpahan wewenang oleh tenaga medis. Pelimpahan wewenang dapat dilakukan secara delegatif maupun mandat. Pelimpahan wewenang secara delegatif dengan disertai pelimpahan tanggung jawab. Pelimpahan wewenang secara mandat diberikan oleh tenaga medis kepada Perawat untuk melakukan sesuatu tindakan medis di bawah pengawasan. Tanggung jawab pada pelimpahan wewenang mandat berada pada pemberi pelimpahan wewenang.

Tidak tertuang dalam UndangUndang Nomor 38 Tahun 2014 tentang Keperawatan mengenai pelimpahan wewenang melaksanakan pelayanan farmasi klinik dispensing sediaan steril di rumah sakit baik secara delegatif maupun secara mandat dari apoteker atau tenaga kefarmasian kepada perawat. Penulis hanya menemukan seperti yang tertuis dalam pasal 33 
ayat (4) huruf c, berbunyi "dalam melaksanakan tugas pada keadaan keterbatasan tertentu sebagaimana dimaksud pada ayat (1) perawat berwenang melakukan pelayanan kefarmasian secara terbatas dalam hal tidak terdapat tenaga kefarmasian. Yang dimaksud dengan pelayanan kefarmasian secara terbatas adalah kegiatan menyimpan dan menyerahkan obat kepada Klien, bukan melaksanakan pelayanan farmasi klinik dispensing sediaan steril.

Penulis mengapresiasi inisiatif dikeluarkannya kebijakan Direktur Rumah Sakit Umum Daerah Sekarwangi Kabupaten Sukabumi yang mengeluarkan Surat Keputusan Direktur mengenai pelimpahan wewenang pelaksanaan pelayanan farmasi klinik dispensing sediaan steril dari apoteker kepada perawat, karena jika tidak dilimpahkan akan menghambat proses pelayanan kepada pasien. Belum bisanya pelaksanaan pelayanan farmasi klinik dispensing sediaan steril dilakukan oleh apoteker dan tenaga teknis kefarmasian karena terbatasnya tenaga apoteker dan tenaga teknis kefarmasian juga kompetensi yang dimiliki oleh apoteker dan tenaga kefarmasian saat ini masih rendah. Dasar dikeluarkannya surat keputusan tersebut diamanatkan oleh Peraturan Bupati Sukabumi Nomor 81 Tahun 2012 tentang Struktur Organisasi dan Tata Kerja Rumah Sakit Umum Daerah Sekarwangi Kabupaten Sukabumi menyatakan:

"RSUD mempunyai tugas pokok melaksanakan penyusunan dan pelaksanaan kebijakan di bidang pelayanan kesehatan dan RSUD mempunyai fungsi perumusan dan penyusunan kebijakan teknis dibidang pelayanan kesehatan."

Keberadaan peraturan kebijakan tidak bisa dilepaskan dengan kewenangan bebas dari pemerintah yang sering disebut dengan freies ermessen. Freies artinya orang yang bebas, tidak terikat dan merdeka. Sementara itu, ermessen berarti mempertimbangkan, menilai, menduga dan memperkirakan. Freies Ermessen berarti orang yang memiliki kebebasan untuk menilai, menduga dan mempertimbangkan sesuatu. Istilah ini kemudian secara khas digunakan dalam bidang 
pemerintahan sehingga freies

Ermessen (pouvoir discretionaire) diartikan sebagai salah satu sarana untuk memberikan ruang bergerak bagi pejabat atau badan-badan administrasi negara untuk melakukan tindakan tanpa harus terikat sepenuhnya pada undang-undang. ${ }^{19}$

Namun penulis ingin mengkritik Surat Keputusan Direktur Rumah Sakit Umum Daerah Sekarwangi Nomor 445/Kep.267-

FARMASI/I/2016 tentang

Pencampuran Obat Steril di RSUD Sekarwangi Kabupaten Sukabumi, dimana pelaksanaan pelayanan farmasi klinik dispensing sediaan steril dilimpahkan kepada perawat dalam bentuk delegasi juga disertai dengan pelimpahan tanggung jawab. Merujuk pada Undang-Undang Nomor 38 Tahun 2014 tentang Keperawatan, menurut penulis, pelimpahan wewenang dari apoteker atau tenaga teknis kefarmasian kepada perawat sebaiknya tidak secara delegatif, tapi secara mandat. Alasannya adalah:

\footnotetext{
19 Juniarso Ridwan dan Achmad Sodik Sudrajat, Op. Cit, Hlm. 150.
}

1. Menurut Peraturan Menteri Kesehatan Republik Indonesia Nomor 72 Tahun 2016 tentang Standar Pelayanan Kefarmasian di Rumah Sakit, dispensing sediaan steril termasuk dalam standar pelayanan farmasi klinik;

2. Pelayanan farmasi klinik, salah satu diantaranya adalah dispensing sediaan steril merupakan pelayanan langsung yang diberikan Apoteker kepada pasien dalam rangka meningkatkan outcome terapi dan meminimalkan risiko terjadinya efek samping karena Obat, untuk tujuan keselamatan pasien (patient safety) sehingga kualitas hidup pasien (quality of life) terjamin;

3. Dispensing sediaan steril harus dilakukan di Instalasi Farmasi dengan teknik aseptik untuk menjamin sterilitas dan stabilitas produk dan melindungi petugas dari paparan zat berbahaya serta 
menghindari terjadinya

kesalahan pemberian obat;

4. Dispensing sediaan steril di rumah sakit merupakan kewajiban dari apoteker dan tenaga kefarmasian yang tidak serta merta dapat dilimpahkan kepada perawat dalam bentuk delegatif disertai dan melepas tanggungjawabnya, karena dispensing sediaan steril merupakan ranah kompetensi dari apoteker dan tenaga teknis kefarmasian;

5. Berbeda dengan delegasi, mengenai mandat, pemberi mandat tetap berwenang untuk melakukan sendiri wewenangnya apabila ia mengizinkan, dan memberi petunjuk kepada mandataris tentang apa yang diinginkanannya. Mandans atau pemberi mandat tetap bertanggungjawab atas tindakan yang dilakukan oleh mandataris.

\section{Implementasi}

Kewenangan Perawat
Pelayanan Farmasi Klinik Dispensing Sediaan Steril di RSUD Sekarwangi Kabupaten Sukabumi

Menurut Mazmanian dan Sebastiar dalam Wahab, implementasi adalah pelaksanaan keputusan kebijakan dasar, biasanya dalam bentuk undang-undang, namun dapat pula berbentuk perintah-perintah atau keputusankeputusan eksekutif yang penting atau keputusan badan peradilan. ${ }^{20}$

Pelaksanaan pelayanan farmasi klinik dispensing sediaan steril di RSUD Sekarwangi Kabupaten Sukabumi belum dilakukan oleh apoteker dan tenaga teknis kefarmasian dengan alasan masih belum memadai sarana di Instalasi Farmasi dan belum terampilnya apoteker dan tenaga teknis kefarmasian, tapi dilaksanakan oleh perawat pelaksana dengan Level Karir Perawat Klinis I-III yang berjumlah 313 orang perawat. Secara tertulis, wewenang pelaksanaan

\footnotetext{
${ }^{20}$ Solichin Abdul Wahab, Pengantar Analisis Kebijakan Publik, Universitas Muhammadiyah Malang Press. Malang, 2008, Hlm. 68.
} 
pelayanan farmasi klinik dispensing sediaan steril di RSUD Sekarwangi Kabupaten Sukabumi tertuang dalam Surat Keputusan Direktur Rumah Sakit Umum Daerah Sekarwangi Nomor 445/Kep.267-

FARMASI/I/2016 tentang

Pencampuran Obat Steril di Rumah Sakit Umum Daerah Sekarwangi Kabupaten Sukabumi, menetapkan bagian ketiga menyatakan:

"Pencampuran obat steril didelegasikan kepada perawat dengan kriteria penanggungjawab shif / ketua tim di ruang perawatan dan telah mendapat pelatihan".

Dalam lampiran Surat

Keputusan Direktur Rumah Sakit Umum Daerah Sekarwangi Kabupaten Sukabumi Nomor 445/Kep.267-FARMASI/I/2016, terdapat 30 daftar nama ketua tim keperawatan yang mendapat pendelegasian pencampuran obat steril. Pada implementasinya ketua tim yang diberikan wewenang melaksanakan pelayanan farmasi klinik dispensing sediaan steril, mendelegasikan kembali (subdelegasi) wewenang ini diberikan kepada perawat pelaksana karena ketua tim keperawatan tidak 24 jam melaksanakan tugas pelayanan.

Upaya yang telah dilakukan oleh RSUD Sekarwangi Kabupaten Sukabumi terkait implementasi pelayanan farmasi klinik dispensing sediaan steril di rumah sakit, yaitu dengan mengirimkan 1 orang apoteker untuk mengikuti "Pelatihan Aseptic Dispensing" pada tanggal 19-23 Maret 2018 di RSUP Nasional Dr. Cipto Mangunkusumo. RSUD Sekarwangi Kabupaten Sukabumi juga sudah membeli 1 unit prasarana Biosafety Cabinet Class II A2 sebagai pendukung pelaksanaan pelayanan farmasi klinik dispensing sediaan steril nanti kedepannya oleh apoteker dan tenaga teknis kefarmasian. Namun, pelaksanaan dispensing sediaan steril belum bisa dilaksanakan oleh apoteker dan tenaga teknis kefarmasian dengan alasan belum tersedianya sarana berupa bangunan sesuai standar yang ditetapkan dan sumber daya manusia apoteker dan tenaga teknis kefarmasian yang kompeten melaksanakan dispensing sediaan 
steril. Jika dispensing sediaan steril dipaksanakan pelaksanaannya oleh apoteker dan tenaga teknis kefarmasian dengan keterbatasan tersebut, tentu akan berimplikasi pada proses pelayanan yang tidak bermutu serta beresiko tinggi untuk terjadinya masalah pada keselamatan pasien.

Berdasarkan analisis beban kerja yang dibuat oleh Bidang Peningkatan dan Pengendalian Mutu RSUD Sekarwangi Kabupaten Sukabumi, dengan jumlah rata-rata kunjungan resep sekitar 400 tindakan perhari dengan proses pencampuran $I V$ admixture dan Total Parenteral Nutrisi, jumlah tenaga yang dibutuhkan adalah 18 orang. ${ }^{21}$ Sementara apoteker dan tenaga teknis kefarmasian yang kompeten melaksanakan dispensing sediaan steril baru 1 orang.

3. Mekanisme

Kewenangan

Melaksanakan

Pelayanan

Farmasi Klinik Dispensing

Sediaan Steril di RSUD

21 Sumber Data: SIMRS, Tanggal Print 9 Mei 2018 jam 11.07 WIB.

\section{Sekarwangi}

Kabupaten

\section{Sukabumi}

Mekanisme

pelimpahan wewenang dapat diartikan sebagai suatu pemberian tugas kepada seseorang atau kelompok dalam menyelesaikan tujuan organisasi. ${ }^{22}$ Berdasarkan Surat Keputusan Direktur Rumah Sakit Umum Daerah Sekarwangi Nomor 445/Kep.267FARMASI/I/2016 tentang Pencampuran Obat Steril di Rumah Sakit Umum Daerah Sekarwangi Kabupaten Sukabumi, menetapkan bagian ketiga menyatakan bahwa pencampuran obat steril didelegasikan kepada perawat dengan kriteria penanggungjawab shif / ketua tim di ruang perawatan dan telah mendapat pelatihan, RSUD Sekarwangi Kabupaten Sukabumi melalui Bidang Peningkatan dan Pengendalian Mutu Rumah Sakit bekerjasama dengan PT. Otsuka Indonesia mengadakan pelatihan dengan tema "Pelatihan

\footnotetext{
${ }^{22}$ JOM Fakultas Hukum, Tanggungjawab Perawat Terhadap Pasien Dalam Pelimpahan Wewenang Dokter Kepada Perawat, Volume II Nomor 1, Februari 2015, Hlm. 10
} 
Pencampuran Obat Injeksi Secara Aseptik". Kegiatan dilaksanakan pada tanggal 10 Oktober 2017 dengan peserta terdiri dari perawat, bidan, apoteker dan tenaga kefarmasian. Materi pelatihan yang disampaikan yaitu Penanganan Obat Injeksi Yang Aman, Teknik Pencampuran Obat Suntik dan Penyiapan Obat Elektrolit Konsentrat. Pelatihan ini dilaksanakan setelah 20 bulan setelah Surat Keputusan Direktur Rumah Sakit Umum Daerah Sekarwangi Nomor 445/Kep.267FARMASI/I/2016 tentang

Pencampuran Obat Steril di Rumah Sakit Umum Daerah Sekarwangi Kabupaten Sukabumi dikeluarkan.

Meninjau kembali masalah mengenai pelimpahan kewenangan yang ada pada Undang-Undang Nomor 38 Tahun 2014 tentang Keperawatan pasal 29 ayat (1) huruf e, dimana tugas dan wewenang dalam menyelenggarakan Praktik Keperawatan, Perawat bertugas sebagai pelaksana tugas berdasarkan pelimpahan wewenang. ${ }^{23}$ Dijelaskan pada pasal 32 ayat (1) Pelaksanaan tugas berdasarkan pelimpahan wewenang sebagaimana dimaksud dalam Pasal 29 ayat (1) huruf e hanya dapat diberikan secara tertulis oleh tenaga medis kepada Perawat untuk melakukan sesuatu tindakan medis dan melakukan evaluasi pelaksanaannya. Belum ada pasal yang menyatakan dan menjelaskan mengenai mekanisme pemberian kewenangan perawat melaksanakan pelayanan farmasi klinik dispensing sediaan steril didalam UndangUndang Nomor 38 Tahun 2014 tentang Keperawatan. Hal tersebut menurut penulis bertentangan dengan asas yang ada dalam UndangUndang Nomor 38 Tahun 2014 tentang Keperawatan yaitu asas pelindungan sebagaimana dijelaskan dalam pasal 2 huruf f yaitu bahwa pengaturan Praktik Keperawatan harus memberikan pelindungan yang sebesar-besarnya bagi Perawat dan masyarakat. Sebagaimana diketahui bahwa pelayanan farmasi klinik dispensing sediaan steril di rumah

${ }^{23}$ Lihat Undang-Undang Nomor 38 Tahun 2014 tentang Keperawatan Pasal 29 Ayat (1) huruf e. 
sakit belum bisa dilakukan oleh apoteker dan tenaga teknis kefarmasian tapi dilaksanakan oleh perawat.

Berdasarkan apa yang disampaikan oleh Kepala Instalasi Farmasi RSUD Sekarwangi Kabupaten Sukabumi mengenai mekanisme pelimpahan wewenang yang baik dari apoteker kepada perawat, penulis sependapat dengan Kepala Instalasi Farmasi RSUD Sekarwangi Kabupaten Sukabumi, bahwa mekanisme pelimpahan yang baik terhadap pelaksanaaan pelayanan farmasi klinik dispensing sediaan steril adalah urutnnya sebagai berikut:

1. Perawat diberikan pelatihan teknik aseptik.

a. Tujuan:

$\begin{array}{lr}\text { Perawat } & \text { memahami } \\ \text { produk/sediaan } & \text { yang } \\ \text { disiapkan } & \text { sangat } \\ \text { diminimalisir } & \text { dari } \\ \text { mikroorganisme } & \text { sehingga } \\ \text { aman diberikan } & \text { kepada } \\ \text { pasien. }\end{array}$

b. Materi Pelatihan:

1) Cuci tangan;
2) Penggunaan alat pelindung diri;

3) Clean room; dan

4) Penanganan limbah.

2. Perawat diberikan pelatihan simulasi aseptic dispensing.

a. Tujuan:

Perawat memamahmi secara langsung teknik-teknik dalam pencampuran obat.

b. Materi Pelatihan:

1) Area kritis dari ampul/vial/infus

Idisposible yang

digunakan;

2) Teknik mencampur/melarutkan/m engambil volume;

3) Kompatibilitas dan inkompatibilitas sediaan obat;

4) Stabilitas penyimpanan obat;dan

5) Perhitungan dan penyimpanan sediaan obat.

3. Validasi kompetensi pelayanan farmasi klinik dispensing sediaan steril dari seorang perawat.

4. Diberikan rekomendasi dari apoteker kepada perawat yang 
kompeten melaksanakan pelayanan farmasi klinik dispensing sediaan steril.

5. Direktur rumah sakit mengeluarkan kebijakan tentang pelimpahan wewenang pelaksanaan pelayanan farmasi klinik dispensing sediaan steril dari apoteker kepada perawat.

6. Validasi ulang terhadap perawat yang diberikan wewenang melaksanaan pelayanan farmasi klinik dispensing sediaan steril dalam waktu 6-12 bulan setelah pelayanan farmasi klinik dispensing sediaan steril dilakukan.

7. Dilakukan supervisi terjadwal (perbulan) oleh apoteker terhadap pelaksanaan pelayanan farmasi klinik dispensing sediaan steril.

Menurut penulis, mekanisme pelimpahan wewenang yang disampaikan oleh Kepala Instalasi Farmasi RSUD Sekarwangi Kabupaten Sukabumi tersebut sejalan dengan asas yang ada dalam Undang-Undang Nomor 38 Tahun 2014 tentang Keperawatan yaitu asas pelindungan sebagaimana penjelasan pasal 2 huruf $\mathrm{f}$ yaitu pengaturan Praktik Keperawatan harus memberikan pelindungan yang sebesar-besarnya bagi Perawat dan masyarakat dan asas keselamatan sebagaimana penjelasan pasal 2 huruf $g$ yaitu Perawat dalam melakukan Asuhan Keperawatan harus mengutamakan kesehatan dan keselamatan Klien.

\section{PENUTUP}

\section{Simpulan}

a. Undang-Undang Nomor 38 Tahun 2014 tentang Keperawatan, tidak menyatakan dan menjelaskan bahwa perawat mempunyai wewenang untuk melaksanakan pelayanan farmasi klinik dispensing sediaan steril, baik di rumah sakit atau di tempat pelayanan kesehatan lainnya. Hal tersebut bertentangan dengan asas pelindungan dan keselamatan pasien, karena undang-undang keperawatan belum mengakomodir permasalahan pelayanan di rumah sakit terkait pelayanan yang diberikan kepada pasien, terutama wewenang 
pelayanan farmasi klinik

dispensing sediaan steril.

Pelayanan farmasi klinik

dispensing sediaan steril di rumah

sakit telah dilaksanakan

pelimpahan wewenang dari apoteker kepada perawat.

Pelimpahan wewenang

melaksanakan pelayanan farmasi klinik dispensing sediaan steril di RSUD Sekarwangi Kabupaten Sukabumi, tertuang dalam kebijakan direktur berupa Surat Keputusan Direktur Rumah Sakit Umum Daerah Sekarwangi tentang Pencampuran Obat Steril di Rumah Sakit Umum Daerah Sekarwangi Kabupaten Sukabumi. Pelaksanaan pelayanan farmasi klinik dispensing sediaan steril dilimpahkan kepada perawat dalam bentuk delegasi, yang disertai dengan pelimpahan tanggung jawab.

b. Implementasi pelayanan farmasi klinik dispensing sediaan steril $\mathrm{d}$ rumah sakit belum diatur oleh peraturan menteri. Pelayanan farmasi klinik dispensing sediaan steril di RSUD Sekarwangi Kabupaten Sukabumi dilaksanakan oleh perawat pelaksana berdasarkan pelimpahan wewenang. Belum dilakukan oleh apoteker dan tenaga teknis kefarmasian dengan karena masih belum memadainya sarana dan prasarana di Instalasi Farmasi dan belum terampilnya apoteker dan tenaga teknis kefarmasian. Dihubungkan dengan asas pelindungan dan keselamatan pasien, sesuai dengan apa yang menjadi pertimbangan dikeluarkannya Surat Keputusan Direktur Rumah Sakit Umum Daerah Sekarwangi Nomor 445/Kep.267-FARMASI/I/2016 tentang Pencampuran Obat Steril di Rumah Sakit Umum Daerah Sekarwangi Kabupaten Sukabumi bahwa: untuk meningkatkan keselamatan pasien dan penggunaan obat yang aman, perlu diatur cara pencampuran obat steril; dan pencampuran obat seril yang selama ini merupakan tugas dari apoteker karena terbatasnta SDM dan sarana kefarmasian, maka harus dibuatkan pendelegasian kepada perawat agar tercapai keselamatan 
pasien dan tidak tertundanya pengobatan pasien.

c. Undang-Undang Nomor 38 Tahun 2014 tentang Keperawatan, mekanisme pemberian kewenangan perawat melaksanakan tugas pelayanan farmasi klinik dispensing sediaan steril di rumah sakit belum diatur mengenai mekanisme pemberian kewenangan perawat melaksanakan pelayanan farmasi klinik dispensing sediaan steril.

\section{Saran}

a. Segera membentuk peraturan menteri, seperti yang diamanatkan dalam Undang-Undang Nomor 38 Tahun 2014 tentang Keperawatan Pasal 34 yang berbunyi "Ketentuan lebih lanjut mengenai tugas dan wewenang Perawat diatur dengan Peraturan Menteri” agar ada peraturan yang mengatur bagaimana sebenarnya wewenang perawat dalam melaksanakan pelayanan farmasi klinik dispensing sediaan steril di rumah sakit. Rumah sakit perlu merubah kebijakan pelimpahan wewenang pelayanan farmasi klinik dispensing sediaan steril dari delegasi menjadi mandat.

b. Perlu adanya perencanaan, monitoring dan evaluasi sistem supervisi pelaksanaan kegiatan pelayanan farmasi klinik dispensing sediaan steril di rumah sakit. Perlu adanya penyusunan peraturan dan kebijakan terkait praktik keperawatan, penyusunan standar dan pedoman pelayanan keperawatan, pengembangan wahana pembelajaran klinik bagi perawat, penyusunan dan pelaksanaan program pembinaan bagi anggota perawat dalam melaksanakan pelayanan farmasi klinik dispensing sediaan steril. Pemerintah, Pemerintah Daerah, Konsil Keperawatan, PPNI membina dan mengawasi praktik keperawatan sesuai fungsi dan tugas masing-masing termasuk didalamnya pelayanan farmasi klinik dispensing sediaan steril.

c. Segera membentuk peraturan menteri, yang mengatur bagaimana mekanisme pelimpahan wewenang pelayanan farmasi klinik dispensing sediaan 
steril dari tenaga kefarmasian kepada perawat.

\section{DAFTAR PUSTAKA}

\section{A. Buku}

Anton M. Moeliono, Kamus Besar Bahasa Indonesia, Jakarta, Balai Pustaka, 1990.

Endang Kusuma Astuti, Transaksi Terapeutik Dalam Upaya Pelayanan Medis di Rumah Sakit, PT. Citra Aditya Bakti, Semarang, 2006.

Ernie Tisnawati Sule dan Kurniawan Saefullah, Pengantar Manajemen, Kencana, Jakarta, 2017.

Hendrik, Etika dan Hukum Kesehatan, EGC, Jakarta, 2013.

Indroharto, Asas-Asas Umum

Pemerintahan yang Baik, dalam

Paulus Efendie Lotulung,

Himpunan Makalah Asas-Asas

Umum Pemerintahan yang Baik,

Citra Aditya Bakti, Bandung, 1994.

Juniarso Ridwan dan Achmad Sodik

Sudrajat, Hukum Administrasi

Negara dan Kebijakan Layanan
Publik, Nuansa Cendekia, Cet. IV, Bandung, 2014.

Philipus M. Hadjon, Perlindungan Hukum Bagi Rakyat Indonesia, Bina Ilmu, Jakarta, 1987.

Solichin Abdul Wahab, Pengantar Analisis Kebijakan Publik, Universitas Muhammadiyah Malang Press. Malang, 2008.

Sri Praptianingsih, Kedudukan Hukum Perawat Dalam Upaya Pelayanan Kesehatan di Rumah Sakit, PT. Raja Grafindo Persada, Jakarta, 2006.

Ta'adi, Hukum Kesehatan Berbasis Pada Keadilan, Genta Publishing, Yogyakarta, 2017.

Tim Penyusun, Kamus Besar Bahasa Indonesia, Edisi Ketiga, Jakarta, 2002.

\section{B. Peraturan Perundang- undangan}

Undang-Undang Dasar Negara Republik Indonesia 1945 setelah amandemen.

Undang-Undang Nomor 32 Tahun 2004 tentang Pemerintah Daerah (Lembaran Negara Republik Indonesia tahun 2004 Nomor 125, 
Tambahan Lembaran Negara Nomor 4437) sebagaimana telah beberapakali diubah terakhir dengan Undang-Undang Nomor 12 Tahun 2008 tentang Perubahan Kedua Atas Undang-Undang Nomor 32 Tahun 2004 tentang Pemerintahan Daerah (Lembaran Negara Republik Indonesia Tahun 2008 Nomor 59, Tambahan Lembaran Negara Republik Indonesia Nomor 4844).

Undang-Undang Nomor 30 Tahun 2014 tentang Administrasi Pemerintahan (Lembaran Negara Republik Indonesia Tahun 2014 Nomor 292, Tambahan Lembaran Negara Republik Indonesia Nomor 5601).

Undang-Undang Nomor 38 Tahun 2014 tentang Keperawatan (Lembaran Negara Republik Indonesia Tahun 2014 Nomor 307, Tambahan Lembaran Negara Republik Indonesia Nomor 5612). Peraturan Menteri Kesehatan Republik Indonesia Nomor 72 Tahun 2016 tentang Standar Pelayanan Kefarmasian di Rumah Sakit (Berita Negara Republik
Indonesia Tahun 2017 Nomor 49).

Departemen Kesehatan Republik

Indonesia, Pedoman

Pencampuran Obat Suntik dan Penanganan Sediaan Sitostatika, Direktorat Bina Farmasi Komunitas dan Klinik, Ditjen Bina Kefarmasiaan dan Alat Kesehatan, 2009.

Departemen Kesehatan Republik Indonesia. Pedoman Dasar Dispensing Sediaan Steril. Direktorat Bina Farmasi Komunitas dan Klinik, Ditjen Bina Kefarmasiaan dan Alat Kesehatan, 2009.

Peraturan Daerah Kabupaten Sukabumi Nomor 25 Tahun 2012 tentang Organisasi Perangkat Daerah Pemerintah Kabupaten Sukabumi (Lembaran Daerah Kabupaten Sukabumi Tahun 2012 Nomor 25, Tambahan Lembaran Daerah Kabupaten Sukabumi Tahun 2012 Nomor 21).

Peraturan Bupati Sukabumi Nomor 81 Tahun 2012 tentang Struktur Organisasi dan Tata Kerja Rumah Sakit Umum Daerah Sekarwangi Kabupaten Sukabumi (Berita 
Daerah Kabupaten Sukabumi Tahun 2012 Nomor 81).

Keputusan Direktur RSUD

Sekarwangi Kabupaten Sukabumi

Nomor 445/Kep/227/12/RS/2016

tentang Panduan Manajemen dan

Penggunaan Obat.

Keputusan Direktur Rumah Sakit

Umum Daerah Sekarwangi Nomor 445/Kep.267-

FARMASI/I/2016 tentang

Pencampuran Obat Steril di

Rumah Sakit Umum Daerah

Sekarwangi

Kabupaten

Sukabumi.

\section{Sumber Lain}

https://kbbi.web.id. Diunduh tanggal

3 Juni 2018, jam 10.14 WIB.
JOM Fakultas Hukum,

Tanggungjawab Perawat

Terhadap Pasien Dalam

Pelimpahan Wewenang Dokter

Kepada Perawat, Volume II

Nomor 1, Februari 2015.

Jurnal. Eksistensi Hukum Perawat Sebagai Tenaga Kesehatan Selain Tenaga Kefarmasian Terhadap Hak Atas Pelayanan Kesehatan.

Pharmaceutical Journal of Indonesia.

Uji Kesesuaian Aseptic Dispensing Berdasarkan Pedoman Dasar Dispensing Sediaan Steril Departemen Kesehatan RI di NICU dan ICU RSUD. Dr. Saiful Anwar Malang, 2017. 